\title{
THE RELIEVING EFFECT OF SUN-DRIED PROTEIN TONIC ON SPORTS FATIGUE
}

\author{
OEFEITO CALMANTE NA FADIGA ESPORTIVA DA PROTEÍNA TÔNICA SECADA AOSOL \\ EL EFECTO CALMANTE EN LA FATIGA DEPORTIVA DE LA PROTEÍNA TÓNICA SECADA AL SOL
}

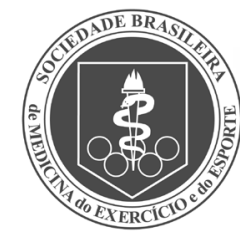

Original Article

ARTIGO ORIGINAL

Artículo Original

\author{
Shuisheng Li' (DD \\ (Public Health) \\ Baoxin Zhang ${ }^{2}$ (D) \\ (Basic Medicine) \\ Pingjun $\mathrm{Ma}^{1}$ (D) \\ (Public Health)
}

\begin{abstract}
1. Department of Physical
Education, Northwest A\&F

University, Yangling, 712100,

Shanxi, China.

2. The sports training department,

Xi,an Physical Education

University, Xi,an ,710068, Shanxi,

China.
\end{abstract}

\section{Correspondence:}

Yangling, 712100, Shanxi, China. gft591267@21cn.com

\begin{abstract}
Fatigue is a comprehensive process that involves many physiological and biochemical factors. It is a normal physiological reaction when human physical or mental activities reach a certain level. In recent years, it has been verified that free radicals are closely related to exercise-induced fatigue. Cardamine bursa purified selenoprotein has good oxygen-free radical scavenging ability and anti-lipid peroxide. It could protect mitochondria, liver, and red blood cells from peroxide injury. Therefore, it was speculated that the purification of selenoprotein Cardamine may play an active role in attenuating exercise-induced fatigue by scavenging free radicals. This study cleared the selenite protein Capsella bursa (SPC) as a research object, and evaluated its structural characteristics in relieving exercise-induced fatigue. The selenoprotein index system for exercise-induced fatigue was constructed by combining two AHP methods, principal component analysis and factor analysis. Purity, subunit composition, amino acid composition and RCM content were evaluated. The corresponding RCM protein was preliminarily predicted. The results showed that $\mathrm{SPCH}$ could significantly prolong the swimming time $(\mathrm{P}<0.01)$, improve the lactate clearance capacity $(P<0.01)$, increase the glycogen content of the liver $(P<0.01)$, and reduce the level of the BUN $(P<0.05)$. Conclusion: SPCH has a good effect in relieving exercise-induced fatigue in mice, so it can be considered for development as a nutritional supplement to alleviate exercise-induced fatigue.
\end{abstract}

Keywords: Capsella capsulosa; selenoprotein; Physical exercise; Fatigue.

\section{RESUMO}

Fadiga é um processo abrangente envolvendo muitos fatores fisiológicos e bioquímicos. Éuma reação fisiológica normal quando as atividades físicas ou mentais humanas atingem um certo nível. Nos últimos anos, verificou-se que os radicais livres estão intimamente relacionados com a fadiga induzida pelo exercício. A selenoproteina purificada de Cardamina bursa tem boa capacidade de depuração de radicais sem oxigénio e de peróxido anti-lípido. Poderia proteger as mitocôndrias, fígado e glóbulos vermelhos de lesões por peróxido. Por conseguinte, especulou-se que a purificação da selenoproteina de Cardamina pode desempenhar um papel activo na atenuação da fadiga induzida pelo exercício por meio de radicais livres de scavenging. Este estudo depurou a proteína selenita Capsella bursa (SPC) como objeto de pesquisa, e avaliou as suas características estruturais no alívio da fadiga induzida pelo exercício. O sistema de índice de selenoproteinas para a fadiga induzida pelo exercício foi construído por meio da combinação dos métodos de AHP, análise principal de componentes e a análise de fatores. Foram avaliados a pureza, a composição sub-unitária, a composição de aminoácidos e o conteúdo do RCM. A proteína correspondente do RCM foi prevista preliminarmente. Os resultados mostraram que o SPCH poderia prolongar significativamente o tempo de natação $(P<0.01)$, melhorar a capacidade de depuração do lactato $(P<0.01)$, aumentar o conteúdo do glicogênio do fígado $(P<0.01)$, e reduzir o nível do BUN $(P<0.05)$. Conclusão: o SPCH tem um bom efeito em aliviar a fadiga induzida pelo exercício em ratos, de modo que pode ser considerado para desenvolvê-lo como um suplemento nutricional para aliviar a fadiga induzida pelo exercício.

Descritores: Capsella capsulosa; selenoproteina; Exercício Físico; Fadiga.

\section{RESUMEN}

La fatiga es un proceso abarcador que envuelve muchos factores fisiológicos y bioquímicos. Es una reacción fisiológica normal cuando las actividades físicas o mentales humanas alcanzan un cierto nivel. En los últimos anos, se verificó que los radicales libres están íntimamente relacionados con la fatiga inducida por el ejercicio. La selenoproteína purificada de Cardamina bursa tiene buena capacidad de depuración de radicales sin oxígeno y de peróxido antilipídico. Podría proteger las mitocondrias, el hígado y los glóbulos rojos de lesiones por peróxido. Por consiguiente, se especuló que la purificación de la selenoproteína de Cardamina puede desempeñar un papel activo en la atenuación de la fatiga inducida por el ejercicio por medio de radicales libres de scavenging. Este estudio depuró la proteína selenita Capsella bursa (SPC) como objeto de investigación, y evaluó sus características estructurales en el alivio de la fatiga inducida por el ejercicio. El sistema de índice de selenoproteínas para a fatiga inducida por el ejercicio fue construido por medio de la combinación dos métodos de AHP, el análisis principal de componentes y el análisis de factores. Fueron evaluados la pureza, la composición sub-unitaria, la composición de aminoácidos y el contenido del RCM. La proteína correspondiente del RCM fue prevista preliminarmente. Los 
resultados mostraron que el SPCH podría prolongar significativamente el tiempo de natación $(P<0.01)$, mejorar la capacidad de depuración del lactato $(P<0.01)$, aumentar el contenido del glicógeno del hígado $(P<0.01)$, y reducir el nivel del BUN $(P<0.05)$. Conclusión: el SPCH tiene un buen efecto en aliviar la fatiga inducida por el ejercicio en ratones, de modo que puede ser considerado para desarrollarlo como un suplemento nutricional para aliviar la fatiga inducida por el ejercicio.

Descriptores: Capsella capsulosa; selenoproteína; Ejercicio Físico; Fatiga.

\section{INTRODUCTION}

Selenoproteins are the main forms of macromolecular selenium in selenium rich plants. The separation and analysis of selenoproteins are of great significance in the prevention and treatment of diseases caused by selenium deficiency. In recent years, studies have found that free radicals are closely related to exercise-induced fatigue. ' It is confirmed that the number of free radicals in liver and muscle significantly increases after exercise fatigue, which indicates that free radicals can be produced by exercise. ${ }^{2}$ The scavenging effect of selenoproteins on lipid peroxide was more obvious than that of sodium selenite and non selenoprotein groups, and the scavenging effect on hydroxyl free radicals was significant. In this study, the index system of selenoprotein for exercise-induced fatigue was constructed by combining the analytic hierarchy process, principal component analysis and factor analysis. ${ }^{3}$ That is to say, the factor layer of the highest structure for the alleviation of exercise-induced fatigue in mice is the determination of BLA content, liver glycogen content and BUN content. The physiological function level of mice in these three aspects can directly reflect the remission of exercise-induced fatigue in mice by purified selenoprotein. ${ }^{4}$

This study combined with analytic hierarchy process (AHP), principal component analysis (PCA) and factor analysis (FA) to construct the model of relieving exercise-induced fatigue. The analytic hierarchy process (AHP) is used to decompose the decision-making problems and related factors into objectives, criteria and other levels for qualitative and quantitative analysis. It can be said that this method is more suitable for the target system with hierarchical and staggered evaluation index, and the target value is not easy to describe quantitatively. At the same time, by combining with the principal component analysis method with dimension reduction statistics, the factor layer of the highest structure for the alleviation of exercise-induced fatigue in mice was completed, including the determination of BLA content, liver glycogen content and BUN content.

The innovation of this study is mainly reflected in two aspects. First, through the combination of analytic hierarchy process (AHP) and principal component dimensionality reduction statistical method, the accuracy of research objectives is improved, and the strong pertinence of this research method is ensured. Secondly, the index system of selenoproteins for exercise-induced fatigue was constructed by combining the analytic hierarchy process (AHP), principal component analysis (PCA) and factor analysis (FAC). The measurement of BLA content, liver glycogen content and BUN content of mice can directly reflect the alleviation of exercise-induced fatigue by purified selenoproteins. Therefore, it has important reference value for human sports fatigue.

\section{RELATED WORK}

Han y et al. Used the interpretive structure model combined with analytic hierarchy process (AHP) to reduce the dimension of multi-dimensional production data and obtain comprehensive evaluation indicators, so as to reduce the impact of multidimensional indicators on DEA model. ${ }^{5}$ Bharathi s V uses the analytic hierarchy process (AHP) to carry out risk assessment. As a multi criteria decision-making technology, bharathi $\mathrm{S} V$ is applied to the risk of the Internet of things, and it is divided into different levels to formulate the control and mitigation plan of information security of the Internet of things. ${ }^{6}$ Ayhan M B et al. Proposed the application of fuzzy analytic hierarchy process (hf-ahp) in supplier evaluation. ${ }^{7}$ Based on the analysis of the characteristics and connotation of water resources carrying capacity (mawrcc), Chi m et al. Adopted the fuzzy comprehensive discrimination method as the evaluation method and the water resources carrying capacity (WRCC) as the evaluation standard. ${ }^{8}$ Ma y et al. Established a fuzzy comprehensive evaluation model based on the characteristics of hierarchy and uncertainty of many factors affecting the safety risk of pipeline passing through the embankment by combining the analytic hierarchy process of uncertainty (AHP) with fuzzy operation [9].

It can be seen from the related research on AHP and selenoprotein by many scholars at home and abroad that the purification of selenoprotein combined with AHP plays an important role in the alleviation of sports fatigue, and the index system of selenoprotein for sports fatigue is constructed by combining AHP, principal component analysis and factor analysis. It can be said that this study can play a positive role and guiding significance in further alleviating sports fatigue.

\section{EXPERIMENTAL DESIGN AND ANALYSIS}

\section{Analysis of the results of exhaustive swimming experiment}

In this study, mice were randomly divided into 7 groups according to body weight, 20 mice in each group, half male and half female. The blank control group (normal saline), positive control group, water extract group and sodium selenite group were set up. During the experiment, all mice were given maintenance feed and fed freely. After 30 minutes of intragastric administration of the test substance, mice were loaded with $5 \%$ body weight of lead skin in the tail, and the mice in each group were put into the swimming box with water depth $>30 \mathrm{~cm}$ and water temperature of $(25 \pm 0.5)^{\circ} \mathrm{C}$. The results are shown in Figure 1 .

It can be seen from Figure 1 and table 1 that during the experiment, the body weight of mice continued to increase, and at the end of the experiment, the body weight of mice increased significantly compared with that at the beginning of the experiment; the increase of body weight of female rats in the blank control group and each experimental group had no significant difference; the body weight gain of male rats in the blank control group and each experimental group had no significant difference Different. In addition to sodium selenite group, there were significant differences between the experimental groups and the blank control group ( $P<0.01)$; compared with the positive control group, the differences between the medium and high dose groups of spch were extremely significant $(P<0.01)$; meanwhile, the spch had obvious advantages in prolonging the exercise endurance of mice, and the medium dose group had better effect Fruit. Compared with the data of other related literatures, the swimming time of each group was lower than the corresponding value in the literature, which may be related to the difference of tail weight-bearing weight or swimming environment in some literatures. 


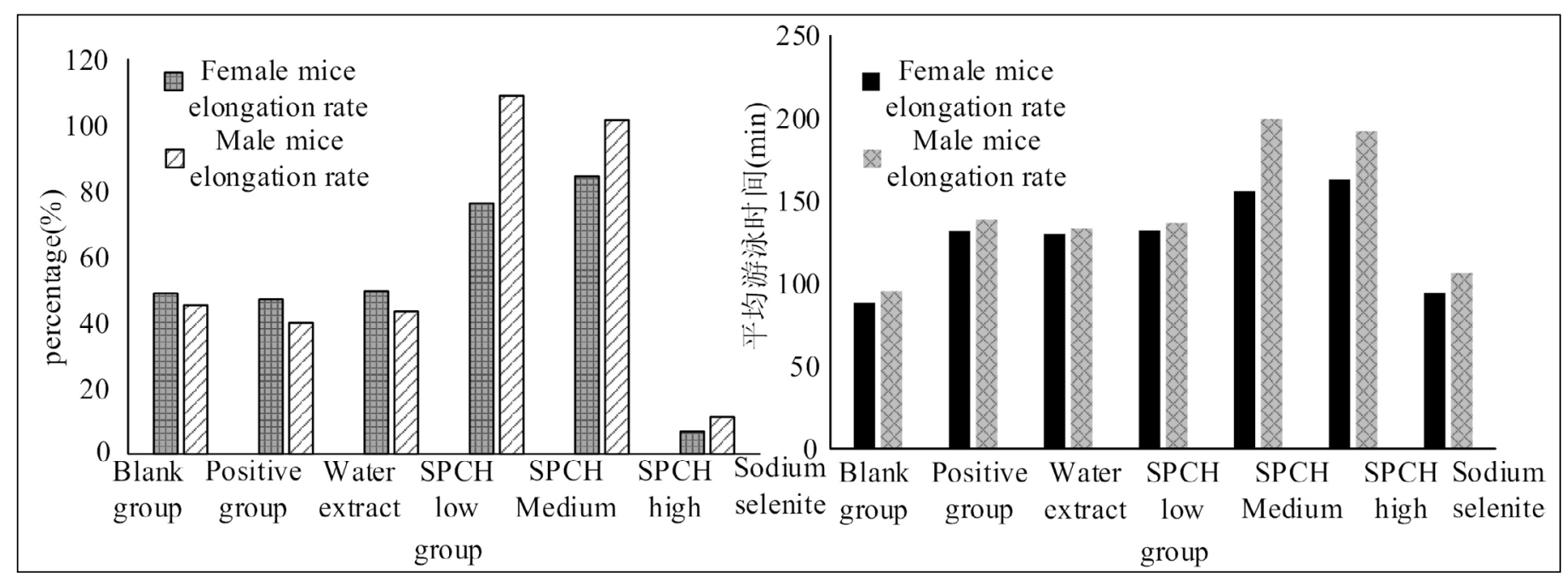

Figure 1. Effect of purified selenoprotein on swimming time of mice.

Table 1. Effect of purified selenoprotein on swimming time of mice.

\begin{tabular}{c|c|c|c}
\hline group & $\begin{array}{c}\text { Number } \\
\text { of mice }\end{array}$ & $\begin{array}{c}\text { Prolongation } \\
\text { rate of average } \\
\text { swimming time / } \\
\text { min in female mice }\end{array}$ & $\begin{array}{c}\text { Average swimming } \\
\text { time / min } \\
\text { prolongation rate } \\
\text { of male mice\% }\end{array}$ \\
\hline Blank control group & 10 & $88.40 \pm 5.03 \# \#$ & $95.40 \pm 0.89 \# \#$ \\
\hline Positive control group & 10 & $131.60 \pm 11.15^{* *} 48.87$ & $138.60 \pm 4.16^{* *} 45.28$ \\
\hline Water extract group & 10 & $130.00 \pm 7.31^{* *} 47.06$ & $133.40 \pm 10.57^{* *} 39.83$ \\
\hline Spch low dose group & 9 & $132.20 \pm 8.73^{* *} 49.55$ & $136.75 \pm 9.07^{* *} 43.34$ \\
\hline Spch medium group & 10 & $155.80 \pm 8.53^{* * \# \# ~ 76.24}$ & $199.40 \pm 4.22^{* * \# \# 109.01}$ \\
\hline Spch high dose group & 10 & $163.0 \pm 12.33^{* * \# \# ~ 84.39}$ & $192.20 \pm 9.78^{* * \# \# 101.47}$ \\
\hline Sodium selenite group & 9 & $94.50 \pm 5.07 \# \# 6.90$ & $106.20 \pm 16.48 \# \# 11.32$ \\
\hline
\end{tabular}

\section{Results of BLA content determination}

In view of the fact that the accumulation of lactic acid is determined by the formation rate and clearance rate of lactic acid, reducing the production of lactic acid or accelerating the clearance of lactic acid can alleviate the effect of exercise-induced fatigue. The content of lactic acid can be used as an index to measure the aerobic metabolism capacity of the body, slow down the generation of fatigue and accelerate the elimination of fatigue.

It can be seen from Figure 2 and table 2 that, compared with the blank control group, the BLA content in the medium and high-dose groups of SPC in female rats was decreased $(P<0.01$ or $P<0.05)$; the BLA content in low -, medium -, and high-dose groups of SPC in male rats was significantly decreased $(P<0.01)$; compared with the positive control group, there was no significant difference in the acceleration of lactic acid elimination between female and male mice; there was no significant difference in Bla content between the water extract group of male rats and the blank control group, and the SPC showed a stronger ability to reduce the accumulation of metabolites (lactic acid) and delay the generation of fatigue.

\section{Determination of glycogen in liver}

One of the reasons for fatigue is that the body consumes too much energy, glycogen can provide a lot of energy for the body, so the amount of glycogen in the body can be used as an index to measure the speed of fatigue or the degree of fatigue.

It can be seen from Figure 3 and Table 3 that compared with the blank control group, the liver glycogen content in the medium and high dose groups of SPC was significantly increased $(P<0.01)$, while the water extract and sodium selenite had no significant effect on the liver glycogen content of mice. The above results show that SPC water

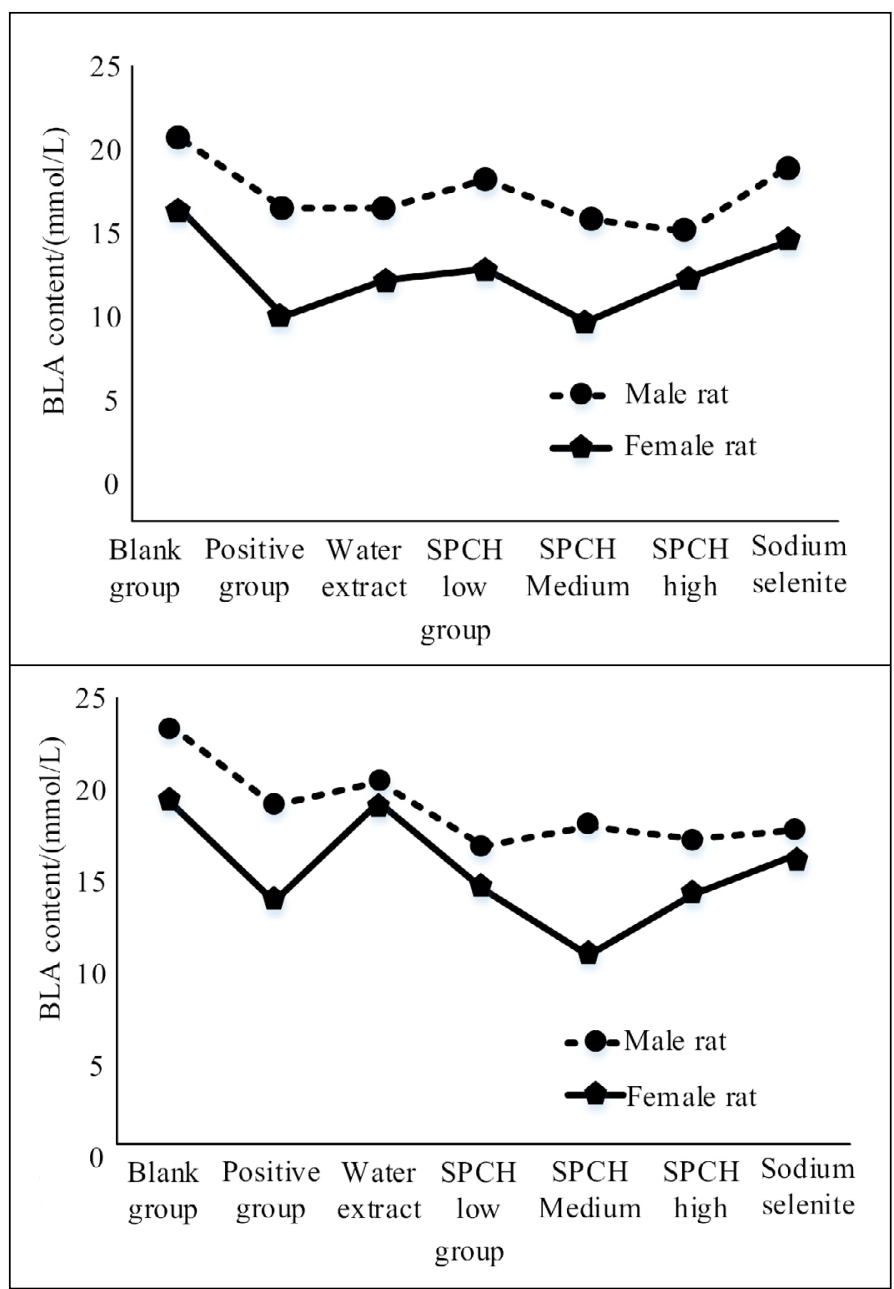

Figure 2. Effect of purified selenoprotein on BLA content after exercise in mice.

Table 2. Effect of purified selenoprotein on BLA content after exercise in mice.

\begin{tabular}{c|c|c|c}
\hline Group & $\begin{array}{c}\text { Number } \\
\text { of mice }\end{array}$ & $\begin{array}{c}\text { BLA content in } \\
\text { female micet/ } \\
\text { (mmol/L) }\end{array}$ & $\begin{array}{c}\text { BLA content in male } \\
\text { mice/(mmol/L) }\end{array}$ \\
\hline Blank control group & 9 & $18.44 \pm 2.14 \cdot \cdot$ & $21.44 \pm 2.07 . \cdot$ \\
\hline Positive control group & 10 & $13.25 \pm 3.25^{* *}$ & $16.54 \pm 2.61^{* *}$ \\
\hline Water extract group & 10 & $14.33 \pm 2.15^{*}$ & $19.87 \pm 0.55 \cdot$ \\
\hline Spch low dose group & 9 & $15.52 \pm 2.68$ & $15.76 \pm 1.18^{* *}$ \\
\hline Spch medium group & 10 & $12.76 \pm 3.09^{* *}$ & $14.50 \pm 3.50^{* *}$ \\
\hline Spch high dose group & 10 & $13.96 \pm 1.41^{*}$ & $15.82 \pm 1.51^{* *}$ \\
\hline Sodium selenite group & 9 & $16.72 \pm 2.23$ & $17.15 \pm 0.66^{* *}$ \\
\hline
\end{tabular}




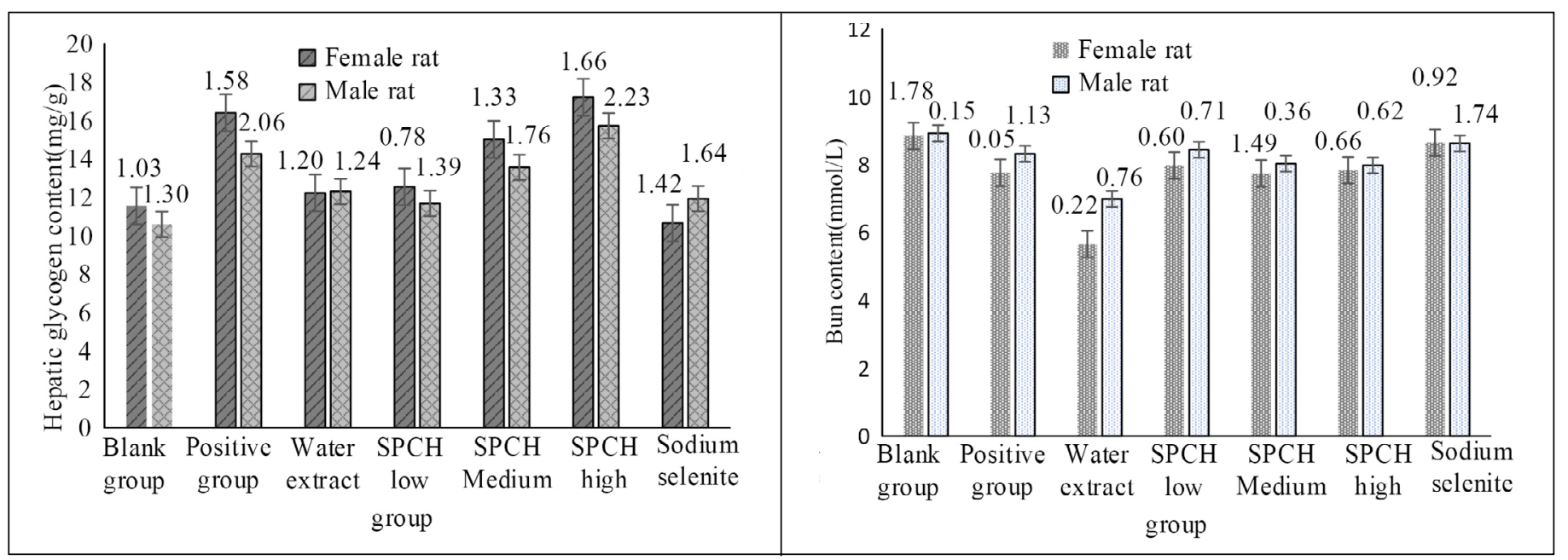

Figure 3. Effects of purified selenoprotein on liver glycogen content and BUN content in mice after exercise.

Table 3. Effects of purified selenoprotein on liver glycogen content and BUN content in mice after exercise.

\begin{tabular}{c|c|c|c|c}
\hline group & $\begin{array}{c}\text { Glycogen } \\
\text { content in } \\
\text { liver of female } \\
\text { rats/(mg/g) }\end{array}$ & $\begin{array}{c}\text { Liver glycogen } \\
\text { content of } \\
\text { male rats/ } \\
\text { ( } \mathbf{m g} / \mathbf{g})\end{array}$ & $\begin{array}{c}\text { Bun content } \\
\text { of female rats/ } \\
\text { (mmol/L) }\end{array}$ & $\begin{array}{c}\text { Bun content } \\
\text { in male rats/ } \\
\text { (mmol/L) }\end{array}$ \\
\hline $\begin{array}{c}\text { Blank control } \\
\text { group }\end{array}$ & $11.56 \pm 1.03 \# \#$ & $10.60 \pm 1.30 \# \#$ & $8.85 \pm 1.78$ & $8.93 \pm 0.15$ \\
\hline $\begin{array}{c}\text { Positive control } \\
\text { group }\end{array}$ & $16.41 \pm 1.58^{* *}$ & $14.27 \pm 2.06^{* *}$ & $7.76 \pm 0.50$ & $8.32 \pm 1.13$ \\
\hline $\begin{array}{c}\text { Water extract } \\
\text { group }\end{array}$ & $12.23 \pm 1.20$ & $12.31 \pm 1.24$ & $5.66 \pm 0.22^{* * \# \#}$ & $6.99 \pm 0.76^{* * \#}$ \\
\hline $\begin{array}{c}\text { Spch low } \\
\text { dose group }\end{array}$ & $12.55 \pm 0.78 \# \#$ & $11.69 \pm 1.39 \#$ & $7.98 \pm 0.60$ & $8.44 \pm 0.71$ \\
\hline $\begin{array}{c}\text { Spch medium } \\
\text { dose group }\end{array}$ & $15.02 \pm 1.33^{* *}$ & $13.56 \pm 1.76^{* *}$ & $7.74 \pm 1.49$ & $8.03 \pm 0.36$ \\
\hline $\begin{array}{c}\text { Spch high } \\
\text { dose group }\end{array}$ & $17.22 \pm 1.66^{* *}$ & $15.73 \pm 2.23^{* *}$ & $7.84 \pm 0.66$ & $7.98 \pm 0.62$ \\
\hline Sodium selenite & $10.66 \pm 1.42 \# \#$ & $11.93 \pm 1.64 \#$ & $8.65 \pm 0.92$ & $8.63 \pm 1.74$ \\
\hline group & & &
\end{tabular}

extract can better maintain the blood glucose level during exercise for the body, so as to better alleviate exercise-induced fatigue. Compared with blank control group and positive control group, the water extract group had significant or extremely significant difference $(P<0.05$ or $P<$ 0.01). Water extract can more effectively reduce the body's use of protein for energy supply during exercise, which may be due to the synergistic effect of other selenium containing substances or other components in water extract with selenoproteins.

\section{CONCLUSION}

The protein was purified by ammonium sulfate precipitation and column chromatography. The SDS-PAGE analysis showed that the protein showed a single band, and the sample reached electrophoretic purity, which laid a foundation for further study on the structure and biological activity of selenoprotein. The molecular weight of the three subunit of selenoprotein was about 37, 39 and 40 KD. The amino acid composition analysis of purified selenoproteins showed that the content of cysteine and methionine was very low, almost zero. It was speculated that selenium entered the protein in the form of Se met and Se Cys, thus forming selenoproteins, which were not detected. The activity of selenoproteins in low-dose group was not obvious, but that in middle and high-dose groups was significant Compared with sodium selenite group, organic selenium (selenoprotein group) has better effect on relieving exercise-induced fatigue, but due to the different content of selenium, the experimental results are not The results showed that spch could significantly prolong the swimming time, increase the content of liver glycogen after exercise, reduce the level of blood urea nitrogen, slow down the production of lactic acid or enhance the ability of lactate clearance, so as to play a more effective role in alleviating exercise-induced fatigue than the water extract of Cardamine fragrans. The results showed that the separation and purification of selenoproteins in water extract was helpful to enhance its activity.

All authors declare no potential conflict of interest related to this article

AUTHORS' CONTRIBUTIONS: The author has completed the writing of the article or the critical review of its knowledge content. This paper can be used as the final draft of the manuscript. Every author has made an important contribution to this manuscript. Pingjun Ma: writing and execution. Shuisheng Li, Baoxin Zhang: data analysis.

\section{REFERENCES}

1. Barrett CW, Short SP, Williams CS. Selenoproteins and oxidative stress-induced inflammatory tumorigenesis in the gut. Cellular and Molecular Life Sciences. 2017; 74(4):607-616.

2. Yao H, Fan R, Zhao X, Zhao W, Liu W, Yang J, et al. Selenoprotein W redox-regulated Ca2+ channels correlate with selenium deficiency-induced muscles Ca2+ leak. Oncotarget. 2016;7(36):57618-57632.

3. Zhang Z, Pedrycz W. Intuitionistic Multiplicative Group Analytic Hierarchy Process and Its Use in Multicriteria Group Decision-Making. IEEE Transactions on Cybernetics. 2018; 21(99):1-13.

4. Zhang J, Yang T. Study of a roof water inrush prediction model in shallow seam mining based on an analytic hierarchy process using a grey relational analysis method. Arabian Journal of Geoences. 2018; 11(7):153.
5. Han Y, Zhou R, Geng Z, Bai J, Ma B, Fan J. A novel data envelopment analysis cross-model integrating interpretative structural model and analytic hierarchy process for energy efficiency evaluation and optimization modeling: Application to ethylene industries. Journal of Cleaner Production. 2020;246(10):118965

6. Bharathi SV. Forewarned is forearmed Assessment of IoT information security risks using analytic hierarchy process. Benchmarking. 2019; 26(8):2443-2467.

7. Ayhan MB. Supplier Evaluation with Hesitant Fuzzy Analytic Hierarchy Process in Bearing Sector and Consistency Analysis. Journal of testing and evaluation. 2020; 48(1):624-646.

8. Chi M, Zhang D, Fan G. Prediction of water resource carrying capacity by the analytic hierarchy process-fuzzy discrimination method in a mining area. Ecological Indicators. 2019; 96(21):647-655. 